\title{
Quercetin-conjugated superparamagnetic iron oxide nanoparticles enhances Nrf2 expression through miR-27a intervention to prevent memory dysfunction in diabetic rats
}

Research

Keywords:

Posted Date: December 1st, 2020

DOI: https://doi.org/10.21203/rs.2.22575/v2

License: (1) This work is licensed under a Creative Commons Attribution 4.0 International License. Read Full License 


\section{Abstract}

The authors have requested that this preprint be withdrawn due to erroneous posting.

\section{Full Text}

The authors have withdrawn this preprint from Research Square. 